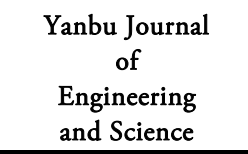

ISSN: 1658-5321
Vol. 1, October $2010(1431 \mathrm{H})$

www.yic.edu.sa/yjes

\title{
OPTIMIZATION OF PROCESSING PARAMETERS FOR A POLYMER BLEND USING TAGUCHI METHOD
}

\author{
Krishna Prasad Rajan ${ }^{1}$, N. R. Veena ${ }^{2}$, Preeti Singh ${ }^{3}$ and G. B. Nando \\ ${ }^{1}$ Department of Chemical Engineering Technology, Yanbu Industrial College, \\ P.O. Box: 30436, Yanbu Al-Sinaiyah, Kingdom of Saudi Arabia. \\ Email:krajan@yic.edu.sa \\ ${ }^{2}$ Research and Post Graduate Department of Chemistry, St.Berchman's College, \\ Changanacherry, 686 101, Kerala, India. \\ ${ }^{3}$ Rubber Technology Centre, Indian Institute of Technology, \\ Kharagpur - 721302, India
}

\begin{abstract}
Blending of thermoplastic polyurethane (TPU) with poly dimethyl siloxane rubber (PDMS) is an attractive approach, where one can combine the strength, toughness and biocompatibility of TPU with flexibility, inertness, high temperature resistance, low temperature flexibility and biocompatibility of PDMS. But the control of the factors determining the overall properties of such a blend like mixing time, temperature and rotor speed is difficult. Hence, an attempt has been made to optimize these processing parameters using statistical technique as per Taguchi. Four factors and three levels were chosen for carrying out the analysis using L9 Orthogonal Array as per Taguchi methodology. Tensile strength and impact strength of the blends under different processing conditions were evaluated as the quality characteristics. Analysis of Variance (ANOVA) was used in determining the significance of factors. The levels of significant factors were optimized using Signal to Noise ratio. It was found that a balance between the two properties were obtained when melt blending was carried out at $190^{\circ} \mathrm{C}$ at $100 \mathrm{rpm}$ rotor speed for 9 minutes for a blend of TPU with PDMS in the proportion of $70 / 30$ by volume. Confirmatory tests were carried out to verify the optimized formulation. Blend morphology studies revealed that PDMS phase gets uniformly dispersed in a matrix of TPU. These blends are expected to be utilized for biomedical applications such as surgical implants and biomedical devices.
\end{abstract}

KEYWORDS: TPU; PDMS; Taguchi method; Optimization; Processing parameters.

\section{INTRODUCTION}

Thermoplastic polyurethanes and silicone rubbers have a long history of applications in biomedical devices. Silicone rubbers, because of the presence of strong silicon - oxygen bonds, imparts unique performance properties such as biocompatibility, superior chemical resistance, good mechanical and electrical properties, low temperature flexibility, physiological inertness and natural clarity or translucence [1]. They have long been known to be biostable and biocompatible hence been used in most biomedical implants and devices. They possess the lower modulus and lower 
hardness used for many device applications. Medical devices made of silicone rubbers exhibit low bacterial action and thrombogenicity, making it an ideal material for surgical drains, feeding tubes, urethral probes and so on. The conventional silicone elastomers may have medium to high ultimate elongations but the disadvantage is that they have very low to moderate tensile strengths. Consequently, the toughness of most biomedical devices based on silicone elastomers is not particularly high. However this disadvantage can be overcome by cross linking to develop useful properties. Once cross linked, the silicone elastomer cannot be re-dissolved or re-melted as it is converted to a thermoset. In contrast to the silicone elastomers, thermoplastic polyurethanes are thermoplastic in nature and have excellent physico mechanical properties. They combine high tensile strengths and elongation with excellent abrasion resistance to form tough albeit fairly high modulus elastomers. They are available in a wide range of hardness. Polyether based polyurethane elastomers have good hydrolytic stability and ability to be sterilized by ethylene oxide gas or gamma irradiation to make them suitable for medical devices.

Combining the biocompatibility and biostability of silicone elastomers with processability and toughness of TPUs is an attractive approach and the resulting blend would appear to be a nearly ideal biomaterial and hence have been chosen as our blend components. Blending of polymers has long been considered an attractive approach to achieve specific end use properties [2]. TPU and PDMS form an immiscible blend system because of dissimilarity in their structures and surface energy differences. The blend morphology plays a very significant role in an immiscible system as it affects blend properties and performance [3]. The blend morphology in turn is controlled by the processing parameters such as, temperature of blending, time of mixing, rotor speed and blend composition. The interrelationships between the above parameters are complex, and the analysis of the system to optimize these factors is a time and labor consuming work. Hence, the analysis using conventional experimental methods are inefficient. The efficient analysis of the complex system using statistical experimental design and the Taguchi method [4-6] are gaining popularity recently. The statistical experimental design can determine the effect of the factors on characteristic properties and the optimal conditions of factors. It uses the tables of orthogonal arrays and analysis of variance (ANOVA) as the tools of analysis. ANOVA can estimate the effect of a factor on the characteristic properties, and an experiment can be performed with the minimum replication using the table of orthogonal array. Conventional statistical experimental design can determine the optimal condition on the basis of the measured values of the characteristic properties, while Taguchi method can determine the experimental condition having the least variability as the optimum condition. The variability of a property is due to 'noise factor', which is a factor difficult to control. On the contrary, the factor easy to control is called 'control factor'. The variability can be expressed by signal to noise $(\mathrm{S} / \mathrm{N})$ ratio [7]. The experimental condition having the maximum $\mathrm{S} / \mathrm{N}$ ratio is considered as the optimal condition, as the variability of characteristics is in inverse proportion to the $S / N$ ratio. Consequently, the Taguchi method can determine the condition of least variability by the $\mathrm{S} / \mathrm{N}$ ratios. Taguchi method is a combination of mathematical and statistical 
techniques used in an empirical study. It is economical for characterizing a complicated process. It uses fewer experiments in order to study all levels of all input parameters, and filters out some effects due to statistical variation. Recently, Park et al. [8] used Taguchi methodology to optimize the adhesion between composite and rubber. Rafizadeh et al. [9] studied the relationship of impact strength of PC/ABS blend based on Taguchi method. Nando and coworkers [10] have optimized the process parameters for a blend of linear low density polyethylene (LLDPE) and PDMS rubber by using Taguchi method. In the present study, statistical experimental design and Taguchi's robust design were carried out simultaneously to optimize the processing parameters for the immiscible blend of TPU and PDMS. The former can be considered as the raw data analysis, and the latter as the $\mathrm{S} / \mathrm{N}$ data analysis. The steps involved in designing, performing and analyzing the experiments using Taguchi method are mentioned below:

1. selection of factors

2. selection of number of levels for the factors

3. selection of the appropriate model assignment of factors to columns

4. conducting the tests

5. analyzing the results

6. confirmation of the experimental results

\section{MATERIALS}

Thermoplastic polyurethane (ESTANE 58202), a polyether based TPU with a specific gravity of 1.25 was supplied by Urethane India Ltd., Madras, India. Polydimethyl siloxane (PDMS ) rubber (silastic WC - 50) containing a small percentage (3.8) of vinyl group and a specific gravity of 1.15 was obtained from Dow Corning Inc. U.S.A.

\section{EXPERIMENTAL}

\subsection{ORTHOGONAL ARRAY AND EXPERIMENTAL PARAMETERS}

Taguchi's orthogonal array table was prepared by choosing four parameters that could affect the blend properties. Table 1 shows the parameters and the levels used in this experiment. The orthogonal array of $L_{9}$ type was used and is represented in Table 2 . $\mathrm{L}$ and subscript 9 means Latin square and the number of experiment, respectively. The numbers I and II in Table 2 indicate the first and second levels of a factor, respectively. Where, I, II and III are levels of factors.

TABLE 1: LEVELS OF FACTORS

\begin{tabular}{|llll|}
\hline Factors & I & II & III \\
\hline Time (minutes) & 6 & 9 & 12 \\
Temperature $\left({ }^{\circ} \mathrm{C}\right)$ & 180 & 190 & 200 \\
Rotor speed (rpm) & 60 & 80 & 100 \\
Blend ratio (TPU: PDMS) & $70: 30$ & $50: 50$ & $30: 70$ \\
\hline
\end{tabular}

TABle 2: L 9 MODEL ACCORDING TO TAGUCHI METHOD

\begin{tabular}{|cllll|}
\hline \multicolumn{5}{|c|}{ Factors } \\
\hline $\begin{array}{c}\text { Experiment } \\
\text { No. }\end{array}$ & B & C & D \\
\hline 1 & I & I & I & I \\
2 & I & II & II & II \\
3 & I & III & III & III \\
4 & II & I & II & III \\
5 & II & II & III & I \\
6 & II & III & I & II \\
7 & III & I & III & II \\
8 & III & II & I & III \\
9 & III & III & II & I \\
\hline
\end{tabular}

\subsection{PREPARATION OF BLENDS}

Melt blending of TPU and PDMS in different proportions by volume such as, 30:70, 50:50, 70:30, was carried out according to nine different combination of the processing parameters (factors) as laid out in the $\mathrm{L}_{9}$ orthogonal array (Table 3 ) in a Brabender Plasticorder (Model PLE - 330). 
The molten mass thus obtained was sheeted out in a laboratory mixing mill $(150 \mathrm{~mm} \mathrm{x}$ $300 \mathrm{~mm}$ ) at room temperature. Sheets of dimension $120 \times 120 \times 2 \mathrm{~mm}$ were obtained from these blends by compression moulding in an electrically heated compression moulding press equipped with a water cooling system at the respective temperature of melt mixing (Table 1) for 4 minutes. After completing the moulding, the sample still under pressure was immediately cooled down to room temperature by cold water circulation through the platens. Sheets were then stripped out of the mould. Samples for various physical property tests were punched from these sheets.

\subsection{MECHANICAL PROPERTY EVALUATION}

Dumbbell specimens were punched out from the moulded sheets using a hollow cutting die (ASTM Die C) and the mechanical properties were determined using a Universal Testing Machine (Hounsfield H10KS) as per ASTM D 412, with a cross head speed of $500 \mathrm{~mm} /$ minute.

\subsection{IMPACT PROPERTY MEASUREMENT}

Standard dumbbell specimens were used to measure the tensile impact property of the blends using a Tensile Impact tester (Ceast $6564 / 000$ ) fitted with a load cell of $7.5 \mathrm{~N}$ at room temperature. The impact strength was expressed in $\mathrm{J} / \mathrm{m}$.

\subsection{BLEND MORPHOLOGY STUDIES}

The blend samples were immersed in liquid nitrogen for 5 minutes and then fractured.

The silicone rubber phase was etched out by dipping the fractured specimen in toluene for 72 hours. The etched samples were subsequently dried in a vacuum oven for 24 hours at $80^{\circ} \mathrm{C}$ to drive out any excess of toluene. The samples were then coated with a thin layer (10-20 $\mathrm{nm}$ ) of gold-palladium alloy. The coating was carried out by placing the specimen in a high vacuum evaporator and vaporizing the metal held in a heated tungsten basket. The blend morphology was analyzed using Scanning electron microscope (JEOL-JSM-5800, Peabody, MA, USA).

TABLE 3: EXPERIMENTAL LAYOUT AS PER L 9 MODEL

\begin{tabular}{|c|c|c|c|c|}
\hline \multicolumn{5}{|c|}{ Factors } \\
\hline \multicolumn{5}{|c|}{ Experiment } \\
\hline No. & A & $\mathrm{B}$ & $\mathrm{C}$ & $\mathrm{D}$ \\
\hline 1 & 6 & 180 & 60 & $70: 30$ \\
\hline 2 & 6 & 190 & 80 & $50: 50$ \\
\hline 3 & 6 & 200 & 100 & $30: 70$ \\
\hline 4 & 9 & 180 & 80 & $30: 70$ \\
\hline 5 & 9 & 190 & 100 & $70: 30$ \\
\hline 6 & 9 & 200 & 60 & $50: 50$ \\
\hline 7 & 12 & 180 & 100 & $50: 50$ \\
\hline 8 & 12 & 190 & 60 & $30: 70$ \\
\hline 9 & 12 & 200 & 80 & $70: 30$ \\
\hline \multicolumn{5}{|c|}{$A=$ time of blending in minutes } \\
\hline \multicolumn{5}{|c|}{$\mathrm{B}=$ temperature of blending in ${ }^{\circ} \mathrm{C}$} \\
\hline \multicolumn{5}{|c|}{$\mathrm{C}=$ rotor speed in $\mathrm{rpm}$} \\
\hline \multicolumn{5}{|c|}{$\mathrm{D}=$ blend ratio (TPU:PDMS) in $\mathrm{vol} / \mathrm{vol}$} \\
\hline
\end{tabular}

\section{RESULTS AND DISCUSSION}

Analysis of Variance (ANOVA) was used to determine the significance of each factor. ANOVA is a statistically based objective decision making tool for detecting any differences in average performance of groups of tested items. It thus determines the effects of the different factor - level combination through an analysis of their variability. The final outcome of the ANOVA table is the determination of $\mathrm{F}$-value. The $\mathrm{F}$ - value is a measure of how statistically significant a particular factor is to the overall experiment. It is the ratio of the variance due to the factors and the variance due to the error. The F-value for each factor from the experiment is compared with the values from existing tables which are generated for different levels of 'confidence'. If the F- value of the experimental factor is much larger than that of the standard value, in the $\mathrm{F}$ examination, 
then this factor bears an important effect in the experiment. Once the significant factors were selected using ANOVA, Signal to Noise Ratio is used in deciding the optimum levels of the factors. Signal to Noise $(\mathrm{S} / \mathrm{N})$ ratio is a performance measure designed by Taguchi and it selects the parameter levels that maximize this ratio. The term signal represents the quality characteristic whereas noise is a measure of the variability (as measured by the variance) of the characteristics. The $\mathrm{S} / \mathrm{N}$ equation depends on the criterion for the quality characteristics to be optimized. There are three standard $\mathrm{S} / \mathrm{N}$ ratios, biggest -is - best, smallest- is - best and nominal-is - best quality characteristics, which are generally applicable in strength, contamination and dimension respectively.

1. Lowest -is-best

$$
\begin{gathered}
\mathrm{S} / \mathrm{N}_{\mathrm{LB}}=-10 \log \left(1 / \mathrm{r} \sum_{\mathrm{i}=1} \mathrm{y}_{\mathrm{i}}^{2)}\right. \\
\mathrm{r}=\text { number of tests in a trial }
\end{gathered}
$$

2. Nominal -is - best

$\mathrm{S} / \mathrm{N}_{\mathrm{NB}}=-10 \log \mathrm{V}_{\mathrm{e}}$ (variance only)

$$
\begin{aligned}
& \text { 3. Highest -is-best } \\
& \mathrm{S} / \mathrm{N}_{\mathrm{HB}}=-10 \log \left(1 / \mathrm{r} \sum_{\mathrm{i}=1}^{\mathrm{r}} 1 / \mathrm{y}_{\mathrm{i}}{ }^{2}\right)
\end{aligned}
$$

Whatever be the type of characteristic, the transformations are such that the $\mathrm{S} / \mathrm{N}$ ratio is always interpreted in the same way, the larger the $S / \mathrm{N}$ ratio better the result.

The physic-mechanical properties for the nine different blends are given in Table 4 .

\subsection{ANOVA SUMMARY AND SIGNAL TO NOISE RATIO ANALYSIS FOR TENSILE STRENGTH}

Blending time, blending temperature, rotor speed and the blend composition are the factors which affect the tensile strength of the blend and hence the same were considered for their effect on tensile strength. From the Fratio we conclude the following. F-calculated value for time is infinity while the F-table value is 10.9 , which indicates that it has a significant effect on the tensile strength. Similarly, the F-calculated values for temperature, rotor speed and blend ratio are infinity while the F-table value is 10.9. This indicates that the temperature of blending, the rotor speed and the blend ratio, all have a significant effect on the tensile strength. Signal to Noise ratio has been determined for each level of the significant factors using the

\begin{tabular}{|c|c|c|c|c|c|c|c|c|c|}
\hline \multirow[b]{2}{*}{ Properties } & \multicolumn{9}{|c|}{ Experiments } \\
\hline & 1 & 2 & 3 & 4 & 5 & 6 & 7 & 8 & 9 \\
\hline Tensile Strength (MPa) & 4.61 & 1.13 & 0.37 & 0.37 & 5.06 & 0.67 & 0.93 & 0.05 & 3.31 \\
\hline Impact Strength $(\mathrm{J} / \mathrm{m})$ & 2.88 & 0.70 & 0.61 & 0.70 & 1.60 & 0.73 & 0.72 & 0.68 & 5.12 \\
\hline Stress@100\%(MPa) & 2.56 & 1.34 & 0 & 0 & 2.70 & 0 & 1.35 & 0.5 & 2.65 \\
\hline Stress@200\%(MPa) & 2.44 & 1.60 & 0 & 0 & 3.03 & 0 & 0 & 0 & 2.97 \\
\hline Stress@ 300\%(MPa) & 3.40 & 0 & 0 & 0 & 3.41 & 0 & 0 & 0 & 3.30 \\
\hline Elongation at Break (\%) & 537 & 257 & 48 & 45 & 638 & 35 & 149 & 30 & 738 \\
\hline
\end{tabular}
formula highest -is - best. Accordingly the levels selected are $A_{2}, B_{2}, C_{3}$, and $D_{1}$. The ANOVA summary and $\mathrm{S} / \mathrm{N}$ ratio calculations based on tensile properties are summarized in Table 5 and Table 6 respectively.

TABle 4: Physico MeChaniCAL PROPERTIES 
TABLE 5: ANOVA SUMMARY ON TENSILE STRENGTH

\begin{tabular}{|l|c|c|c|c|}
\hline \multicolumn{1}{|c|}{ Factors } & $\begin{array}{c}\text { Sum of } \\
\text { squares(SS) }\end{array}$ & $\begin{array}{c}\text { Degree of } \\
\text { freedom (N) }\end{array}$ & $\begin{array}{c}\text { Variance } \\
\text { VF=(SS/N) }\end{array}$ & $\begin{array}{c}\text { F-CAL } \\
\text { Value } \\
\text { (VF/VO) }\end{array}$ \\
\hline Time & 0.73 & 2 & 0.37 & $\propto$ \\
Temperature & 0.68 & 2 & 0.34 & $\propto$ \\
Rotor speed & 0.41 & 2 & 0.21 & $\propto$ \\
Blend ratio & 28.6 & 2 & & \\
\hline SS & 30.42 & 14.3 & \multicolumn{2}{|c}{ VO=0 } \\
SS(T) & 30.42 & 6 & & \\
SSe & 0 & 14 & & \\
\hline
\end{tabular}

$F$ ratio indicates whether effect is significant or not. Table value for $F$ ratio $F(2,6)$ at $99 \%$ confidence level is 10.9 .

TABLE 6: S/N RATIO VALUES FOR TENSILE STRENGTH

\begin{tabular}{|c|c|c|c|c|}
\hline Levels & $\begin{array}{c}\text { Time } \\
\text { A }\end{array}$ & $\begin{array}{c}\text { Temperature } \\
\text { B }\end{array}$ & $\begin{array}{c}\text { Rotor speed } \\
\text { C }\end{array}$ & $\begin{array}{c}\text { Blend ratio } \\
\text { D }\end{array}$ \\
\hline I & 18.32 & 18.25 & 18.14 & 22.39 \\
II & 18.95 & 19.07 & 15.69 & 8.91 \\
III & 15.50 & 15.40 & 19.02 & 0.81 \\
\hline
\end{tabular}

4.2 ANOVA SUMMARY AND SIGNAL TO NOISE RATIO ANALYSIS FOR IMPACT STRENGTH

Since the blending time, blending temperature, rotor speed and the blend composition are the factors expected to affect the impact strength, the same were considered for their effect on the impact strength of the blends.

From the F-ratio, following conclusions are drawn. F-calculated value for time is 350 , for temperature is 341.67 , for rotor speed is 363.33 and for blend ratio is 2100 . Since the F-table value is 10.9 , it indicates that all the factors are highly significant. Signal to Noise ratio has been determined for each level of the significant factors using the formula highest-is-best. Accordingly the levels selected are $A_{3}, B_{3}, C_{2}$, and $D_{1}$. It was found that the combination of the levels $A_{2}, B_{2}, C_{3}$, and $D_{1}$ gives better physico mechanical properties compared to the combination of the levels $A_{3}$, $\mathrm{B}_{3}, \mathrm{C}_{2}$, and $\mathrm{D}_{1}$. Table 4 shows the physico mechanical properties of the blends prepared by the combination of the levels $A_{2}, B_{2}, C_{3}$, $\mathrm{D}_{1}$ (Experiment 5) and $\mathrm{A}_{3}, \mathrm{~B}_{3}, \mathrm{C}_{2}, \mathrm{D}_{1}$ (Experiment 9). Hence $A_{2}, B_{2}, C_{3}$ and $D_{1}$ are chosen as the optimum set of levels for the factors considered here.

The ANOVA summary and $\mathrm{S} / \mathrm{N}$ ratio calculations based on impact strength are summarized in Table7 and Table 8 respectively. In order to verify the optimum process conditions selected, confirmatory experiments were performed. The physico mechanical properties of the blend thus prepared are shown in Table 9. 
Yanbu Journal of Engineering and Science Vol. 1 (2010)

TABLE 7: ANOVA SUMMARY FOR IMPACT STRENGTH

\begin{tabular}{|l|c|c|c|c|}
\hline \multicolumn{1}{|c|}{ Factors } & Sum of squares(SS) & $\begin{array}{c}\text { Degree of freedom } \\
(\mathrm{N})\end{array}$ & $\begin{array}{c}\text { Variance } \\
\text { VF=(SS/N) }\end{array}$ & $\begin{array}{c}\text { F-CAL } \\
\text { Value } \\
\text { (VF/VO) }\end{array}$ \\
\hline Time & 2.1 & 2 & 1.05 & 350 \\
Temperature & 2.05 & 2 & 1.025 & 341.67 \\
Rotor speed & 2.18 & 2 & 6.3 & 2100.0 \\
Blend ratio & 12.6 & 2 & & VO=0.7323X10 \\
\hline S & 18.93 & 8 & & \\
SS(T) & $7.074 \times 10^{3}$ & 14 & & \\
SSe & $4.394 \times 10^{3}$ & 6 & & \\
\hline
\end{tabular}

TABLE 8: S/N RATIO VALUES FOR IMPACT STRENGTH

\begin{tabular}{|l|c|c|c|c|}
\hline \multirow{2}{*}{ Levels } & Time & Temperature & Rotor speed & Blend ratio \\
A & B & \\
\hline I & 14.39 & 14.46 & 14.45 & 20.46 \\
II & 10.31 & 10.23 & 19.12 & 6.65 \\
III & 19.12 & 19.10 & 10.15 & 5.99 \\
\hline
\end{tabular}

TABLE 9: OPTIMUM PHYSICO MECHANICAL PROPERTIES

\begin{tabular}{|c|c|c|c|c|c|c|}
\hline Properties & $\begin{array}{c}\text { T.S } \\
(\mathrm{MPa})\end{array}$ & $\begin{array}{c}\text { Stress at } \\
100 \%(\mathrm{MPa})\end{array}$ & $\begin{array}{c}\text { Stress at } \\
200 \%(\mathrm{MPa})\end{array}$ & $\begin{array}{c}\text { Stress at } \\
300 \%(\mathrm{MPa})\end{array}$ & $\begin{array}{c}\text { Elongation at } \\
\text { break }(\%)\end{array}$ & $\begin{array}{c}\text { Impact } \\
\text { strength }(\mathrm{J} / \mathrm{m})\end{array}$ \\
\hline Values & 5.32 & 2.68 & 3.0 & 3.65 & 640 & 3.00 \\
\hline
\end{tabular}

\subsection{BLEND MORPHOLOGY STUDIES}

The blend morphology studies of the samples processed at optimum processing conditions showed the uniform distribution of spherical silicone rubber phase in the TPU matrix (Fig 1). Whereas, the morphology of samples prepared in other conditions showed irregular distribution of silicone rubber phase (Fig 2). The enhancement of properties such as tensile strength and impact strength can be attributed to this uniform distribution of dispersed phase.

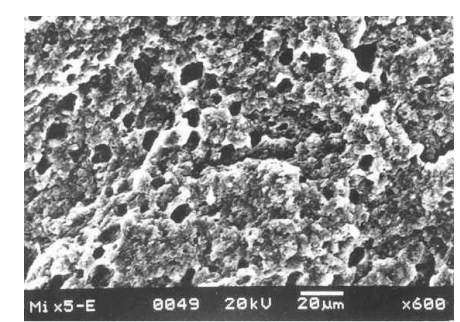

Fig.1. Scanning electron micrograph showing the uniform dispersion of silicone rubber in a TPU matrix under the optimum processing conditions.

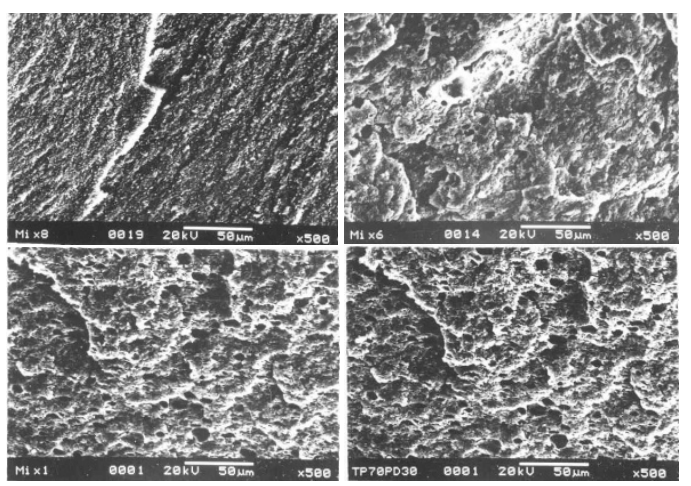

Fig. 2. Scanning electron micrographs showing irregular distribution of silicone rubber phase

\section{CONCLUSIONS}

Taguchi method has been applied to optimize the processing conditions of TPU- PDMS blends. From the experimental results it was found that all the four factors, blending time, blending temperature, rotor speed and blend composition have profound influence on the blend properties. Thus blending TPU with PDMS in $70 / 30$ vol\% at a temperature of $190^{\circ} \mathrm{C}$ for 9 minutes at $100 \mathrm{rpm}$ rotor speed 
gives a balanced set of properties. Morphology studies for the blend processed under these optimum parameters showed a uniform distribution of silicone rubber phase over a TPU matrix, which shows the effectiveness of the optimum processing parameters.

\section{REFERENCES}

[1] Bhowmick A. K. and Stephens H.L., Handbook of elastomers, Marcel Dekker Inc. New York , 2001.

[2] Puyvelde P.V, Velankar S., Moldenaers P., Rheology and morphology of Compatibilized polymer blends, Current Opinion in Colloid \& Interface Science. 6, 457-463, 2001.

[3] Garton A , The characterization of blend microstructure. Polym. Eng. Sci 22 (2), 124-129, 1982.

[4] Yang R.D., Mather R.R., Fortheringham A.F. The application of factorial experimental design to the processing of polypropylene fibres. J. Mater. Sci. 36, 3097-3101, 2001.

[5] Park S.K., Kim K.D., Kim H.T., Preparation of silica nanoparticles: determination of the optimal synthesis conditions for small and uniform particles, Colloids Surf., A: Physicochem. Eng. Aspects 197(1) 7-17, 2002.

[6] Liu J.M., Lu P.Y., Wong W.K., Studies on modifications of ITO surfaces in OLED devices by Taguchi methods, Mater. Sci. Eng. B 85(2-3) 209-211, 2001.

[7] Roy R K., A Primer on the Taguchi Method, Van Nostrand Reinhold, New York, 1990.

[8] Park B Y, Jung S K, Yun J Y, Jung B, Won Y G., Optimization of adhesion between composite and rubber using the Taguchi method. International SAMPE symposium and exhibition, Daejon, South Korea, 47, 1573-1578. 2002.

[9] Rafizadeh M, Morshedian J, Ghasemi I, Bolouri A., Experimental relationship for impact strength of PC/ABS blend based on the Taguchi method, Iran. Poly. Journal, 14 (10), 881-889, 2005.

[10] Sureshkumar M S, Naskar K, Nando G B, Bhardwaj Y K, Optimization of process parameters of immiscible blends of linear low density polyethylene and polydimethyl siloxane rubber using Taguchi methodology, PolymerPlastics Technology and Engineering, 57, 341-345, 2008. 


$$
\begin{aligned}
& \text { تحديد أفضل عمليات خلط اللاائن بإستخدام طريقة تاجوشي } \\
& \text { كرشنا بر اساد راجان'، إن آر فيينا'، برييتي سنغَّ و جي بي ناندوَّ }
\end{aligned}
$$

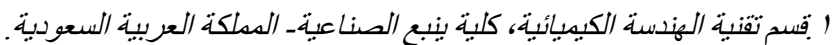

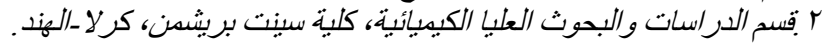

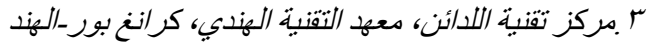

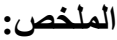

تشمل هذه الدر اسة محاولة لتحديد أفضل ظروف عمليات لخلط لدائن TPV مع PDMS بإستخدام طرق التحليل الإحصائية مثل طريقة تاجوشي.

لقد تم دراسة أثر ظروف الخلط المختلفة على خاصني مقاومة الثد ومقاومة الصدمات للائن الناتجة عن عمليات الخلط.

لقد نم التوصل إلى أن هناك توازن بين هاتين الخاصيتين عندما يتم خلط اللائن في حالة الذوبان عند درجة

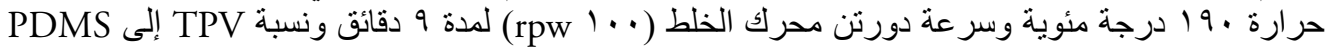

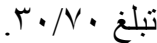

إن الدراسات والفحوصات المختلفة على التركيب البلوري للائن الناتجة عن عمليات الخلط أثبتت أن طور يكون منتشر أ بشكل منتظم في مصفوفة TPU المنتظمة هذه الخلائط من اللدائن سوف يتم إستخدامها للاتيا لأغر اض بيولوجية طبية. 